g,PXYM

Genual Profesi Kesehatan Masyarakat

http://jurnal.bhmm.ac.id/index.php/jpkm

${ }^{\circledR}$ Corresponding Author.

email address : helgapuspa76@gmail.com

Received :1 Januari 2021 Revised : 2 Februari 2021 Accepted : 1 April 2021

\title{
Kajian Faktor-faktor Terkait Perilaku Merokok pada Remaja di Desa Krajan Kecamatan Parang Kabupaten Magetan
}

\author{
${ }^{\square}$ Helga Puspawinarta, Aries Prasetyo \\ Prodi Sanitasi Program D3 Kampus Magetan, \\ Poltekkes Kemenkes Surabaya, Indonesia
}

\begin{abstract}
ABSTRAK
Perilaku merokok adalah perilaku yang dapat membahayakan kesehatan bagi manusia, beberapa orang mulai merokok ketika dia masih berusia remaja. Penelitian ini bertujuan untuk mengetahui faktor yang terkait dengan perilaku merokok pada remaja di Desa Krajan Kecamatan Parang Kabupaten Magetan. Penelitian ini merupakan jenis penelitian deskriptif. Populasi dan sampel yaitu seluruh remaja laki-laki yang merokok di Desa Krajan, Kecamatan Parang, Kabupaten Magetan sejumlah 67 remaja laki-laki, teknik pengambilan sampel total sampling dan pengumpulan data melalui kuesioner. Analisis data menggunakan analisis tabel. Hasil dari penelitian menunjukan bahwa faktorr-faktor yang terkait dengan perilaku remaja dalam merokok adalah sebagai berikut : Predisposing faktor yang terdiri dari pengetahuan kurang baik (62,69\%), sikap kurang baik (59,70\%), kesulitan dalam belajar (55,22\%), ingin terlihat keren (59,70\%), ingin mencoba merokok (89,56\%) dan tindakan kurang baik (59,70\%), Enabling factor yakni tersedianya uang saku remaja (100\%), Reinforcing faktor yang terdiri dari faktor orang tua merokok (67,16\%) orang tua bercerai (37,31\%), tidak tinggal bersama orang tua (22,39\%), teman sebaya perokok (82,09\%), ajakan teman merokok (74,63\%) dan iklan rokok (61,19\%). Faktor yang dominan terkait dengan perilaku remaja dalam merokok sebagai berikut : keinginan mencoba (Presdisposing factor), uang saku (Enabling factor), teman sebaya perokok dan ajakan teman (Reinforcing factor).
\end{abstract}

Kata kunci: Remaja, Merokok, Predisposing, Enabling. Reincorcing

PENDAHULUAN

Merokok adalah suatu bentuk perilaku yang banyak ditemui di semua kalangan masyarakat. Menurut Peraturan Pemerintah Nomor 109 tahun 2012 tentang Pengamanan Bahan yang Mengandung Zat Adiktif berupa Produk Tembakau bagi Kesehatan, rokok ialah suatu produk tembakau yang dibakar dan dihisap atau dihirup asapnya, temasuk bentuk rokok kretek, rokok putih, cerutu dan bentuk rokok lainnya (Purnomo, Roesdiyanto, \& Gayatri, 2018).
Perilaku merokok ialah perilaku yang dapat membahayakan kesehatan bagi manusia, tetapi masih banyak orang yang melakukan aktivitas merokok, bahkan orang mulai merokok ketika dia masih berusia remaja. Walaupun semua orang sudah mengetahui tentang bahaya dari rokok, tetapi hal ini tidak membuat orang berhenti merokok. (Febrijanto \& Fikriyah, 2012)

Perilaku merokok pada remaja adalah hal yang tidak asing lagi. Kebiasaan merokok 
dianggap dapat memberikan kenikmatan bagi perokok, namun disisi lain dapat menimbulkan dampak yang buruk bagi perokok itu sendiri maupun orang lain yang ada disekitarnya. Motivasi yang melatar belakangi merokok ialah untuk mendapatkan pengakuan, menghilangkan kekecewaan, dan menganggap perbuatannya itu tidak melanggar norma. Kegiatan merokok yang dilakukan oleh remaja biasanya dilakukan di depan orang lain, terutama merokok di depan kelompoknya atau teman sebanyanya. (Fatmawati, 2010)

Sekarang ini Indonesia menghadapi ancaman yang serius akibat meningkatnya jumlah perokok, prevalensi perokok laki-laki di Indonesia menjadi yang tertinggi di dunia dan diprediksi lebih dari 97 juta masyarakat Indonesia terpapar asap rokok. Peningkatan prevalensi merokok terbesar pada kelompok remaja atau anak-anak usia dini. Riskesdas 2018 menunjukan bahwa terdapat peningkatan prevalensi merokok usia 18 tahun dari 7,2\% menjadi 9,1\% (Kemenkes, 2019).

Menurut Kurt Lewin, perilaku merokok adalah fungsi dari lingkungan dan individu, yang artinya perilaku merokok selain disebabkan oleh dirinya sendiri juga disebabkan oleh faktor lingkungan. Faktor dari dalam diri remaja dapat dilihat dari kajian perkembangan remaja. Remaja mulai merokok karena adanya krisis aspek psikososial yang dialami ketika seorang remaja mencari jati dirinya. Gejala awal mengkonsumsi rokok yang mungkin terjadi ialah batuk-batuk, lidah terasa getir, dan perut mual. Namun sebagian dari remaja mengabaikan gejala tersebut dan berlanjut menjadi kebiasaan dan akhirnya menjadi ketergantungan. Hal ini disebabkan dari sifat nikotin, yang jika dihentikan secara tibatiba akan menimbulkan stres. Pada dasarnya perilaku merokok merupakan perilaku yang dipelajari. Hal ini berarti terdapat pihakpihak yang berpengaruh besar dalam perilaku merokok pada remaja. (Komasari, 2013).

Faktor penyebab perilaku merokok pada remaja adalah predisposing factor merupakan faktor dari diri sendiri atau internal terdiri dari pengetahuan tentang merokok, sikap tentang merokok dan faktor psikologis remaja, selain itu juga enabling factor yaitu pemberian uang saku sehari-hari yang dapat mendorong remaja dalam membeli rokok. Sedangkan faktor lingkungan atau eksternal yaitu reinforcing factor yang terdiri dari orang tua merokok, orang tua bercerai, tidak tinggal bersama orang tua, teman sebaya perokok, ajakan teman merokok dan iklan rokok. Berdasarkan hasil observasi awal di Desa Krajan jumlah perokok sebagian adalah perokok remaja. Sehingga perlu dikaji faktor-faktor tersebut terkait dengan perilaku remaja dalam merokok.

\section{METODE PENELITIAN}

Jenis penelitian yang digunakan adalah deskriptif dengan desain cross sectional, penelitian ini bertujuan mendeskripsikan faktor yang membuat remaja laki-laki merokok di Desa Krajan Kecamatan Parang Kabupaten Magetan. Populasi pada penelitian seluruh remaja yang merokok di Desa Krajan sebanyak 67 orang dan sampel diambil keseluruhan remaja yang merokok di Desa Krajan (total sampling) sebanyak 67 orang. Penelitian dilaksanakan di Desa Krajan Kecamatan Parang Kabupaten Magetan pada tanggal 15 April - 15 Mei 2020. Pengumpulan data dilakukan dengan cara membagikan kuesioner kepada responden. Data yang terkumpul dianalisis secara deskriptif dengan pendekatan kunatitatif disajikan dalam bentuk frekuensi dan persentase, sehingga didapatkan gambaran faktor yang dominan menyebabkan perilaku remaja dalam merokok.

\section{HASIL DAN PEMBAHASAN \\ Karateristik Responden}

Karateristik responden dari hasil survei perilaku merokok pada remaja di Desa Krajan Kecamatan Parang Kabupaten Magetan dapat dijelaskan pada Tabel 1.

Karateristik responden dari hasil survei dapat diketahui sebagian besar berpendidikan SMA sebanyak 60 orang $(89,55 \%)$ dan semuanya berjenis kelamin laki-laki (100\%). Selain itu hasil hasil survei menunjukkan kelompok umur 16-19 tahun merupakan kelompok yang banyak merokok. Hasil survei tersebut relevan dengan data InfoDatin (2015), yang menunjukkan bahwa usia merokok pertama kali paling tinggi pada kelompok umur 15 - 19 tahun. 
Hasil Penelitian Faktor-faktor Perilaku Merokok Pada Remaja di Desa Krajan Kec. Parang Kabupaten Magetan.

Hasil survei beberapa faktor dalam perilaku merokok pada remaja di Desa Krajan Kecamatan Parang Kabupaten Magetan dapat dijelaskan pada Tabel 2.

Hasil survei faktor predisposisi (predisposing factor) dalam perilaku remaja merokok dapat dijelaskan ada dua faktor yang dominan, yakni faktor pengetahuan remaja tentang rokok (pengertian rokok dan efek samping) sebagian besar kurang baik atau sebanyak 42 orang $(62,69 \%)$, faktor psikologis yaitu ingin mencoba merokok sebanyak 60 responden $(89,56 \%)$. Hasil penelitian ini sesuai dengan pernyataan yaitu pengetahuan sangat berpengaruh karena pengetahuan menentukan sikap dan tindakan remaja terhadap perilaku merokok orang-orang yang ada disekitarnya (Alamsyah, 2009). Pengetahuan merupakan hasil penginderaan manusia atau hasil tahu seseorang terhadap objek melalui indera yang dimilikinya. Pengetahuan merupakan segala sesuatu yang dilihat, dikenal, dimengerti terhadap suatu objek tertentu yang ditangkap melalui pancaindera yakni, indera pendengaran, penglihatan, penciuman, perasaan dan perabaan (Notoatmodjo, 2007).

Sejalan dengan penelitian Rochayati (2015), menunjukkan bahwa remaja yang me- rokok memiliki pengetahuan yang kurang baik tentang rokok, jumlah remaja yang memiliki pengetahuan kurang baik lebih banyak dari pada jumlah remaja yang memiliki pengetahuan baik tentang rokok, lebih dari setengah responden yang memiliki pengetahuan yang kurang baik tentang rokok. Seorang remaja yang berpengetahuan baik akan memilki perilaku yang baik, begitupun sebaliknya seorang remaja yang berpengetahuan kurang baik akan memiliki perilaku yang kurang baik pula. Remaja yang mempunyai pengetahuan kurang baik tentang rokok, bahaya rokok dan dampak dari rokok akan mudah menjadi seorang perokok, tetapi berbeda dengan remaja yang mempunyai pengetahuan baik tentang rokok, bahaya rokok, dan dampak dari rokok mereka akan berusaha untuk menghindari merokok.

Selain itu faktor psikologis yang berpengaruh dalam perilaku merokok pada remaja yaitu remaja ingin mencoba untuk merokok. Remaja mempunyai keinginan tinggi akan rasa dari rokok atau mempunyai rasa penasaran yang tinggi mengenai rasa dari rokok sehingga menyebabkan remaja mulai untuk mencoba hal yang baru yaitu merokok. Berawal dari cobacoba merokok yang berujung menjadi kebiasaan merokok (Melda, 2017). Rasa keingintahuan remaja terhadap rokok membuatnya ingin mencoba merokok, masa ini muncul karena keadaan remaja yang sedang dalam fase

Tabel 1

Karateristik Responden Perilaku Merokok pada Remaja di Desa Karajan Kecamatan Parang Kabupaten Magetan

\begin{tabular}{llcc}
\hline No. & Karateristik Responden & Frekuensi (n) & Persentase (\%) \\
\hline 1. & Pendidikan & 7 & 10,45 \\
& SMP & 60 & 89,55 \\
& SMA & 67 & 100 \\
& Jumlah & & \\
2. $\quad$ Kelompok Umur & 7 & 10,45 \\
& 13-14 & 60 & 89,55 \\
& 16-19 & 67 & 100 \\
& Jumlah & & 100 \\
3. Jenis Kelamin & 67 & 0 \\
& Laki-Laki & 0 & 100 \\
& Perempuan & 67 & \\
& Jumlah & & \\
\hline
\end{tabular}

Sumber: Data Primer Diolah, 2020 
transisi, dimana dalam setiap adanya transisi suatu perubahan, status individu menjadi tidak jelas karena terdapat keraguan akan peran yang harus dilakukan. Masa remaja individu bukan lagi seorang anak-anak dan juga bukan orang dewasa. Di sisi lain, status remaja yang tidak jelas ini memberikan keuntungan karena status tersebut memberi ruang dan waktu kepada seorang remaja untuk mencoba gaya hidup yang berbeda dan menemukan pola perilaku, nilai dan sifat yang paling sesuai bagi dirinya (Nasution, 2007). Berdasarkan penelitian yang dilakukan Baharudin (2017), menunjukkan bahwa ada perbedaan perilaku merokok antara siswa yang memiliki alasan psikologis yang mengatakan ingin mencoba merokok dan tidak ingin mencoba merokok, atau ada hubungan yang bermakna antara yang mengatakan ingin mencoba merokok dengan perilaku merokok pada responden.

Hasil survei faktor pemungkin (enabling factor) yakni tersedianya uang saku berpengaruh terhadap perilaku merokok pada remaja di Desa Krajan Kecamatan Parang kabupaten Magetan. Hasil survei didapatkan semua responden yang merokok $(100 \%)$ mengatakan bahwa mempunyai uang saku yang berlebih.

Uang saku adalah uang yang dibawa untuk keperluan sewaktu-waktu atau uang diberikan untuk dibelanjakan sewaktu-waktu (untuk anak yang belum punya penghasilan dan jumlah

Tabel 2

Hasil Survei Predisposing Factor dalam Perilaku Merokok Pada Remaja di Desa Karajan Kecamatan Parang Kabupaten Magetan

\begin{tabular}{|c|c|c|c|}
\hline No. & Faktor Perilaku & Frekuensi (n) & Persentase $(\%)$ \\
\hline \multirow[t]{4}{*}{ A. } & Pengetahuan tentang rokok & & \\
\hline & Baik & 25 & 37,31 \\
\hline & Kurang & 42 & 62,69 \\
\hline & Jumlah & 67 & 100 \\
\hline \multirow[t]{4}{*}{ B. } & Sikap tentang merokok & & \\
\hline & Baik & 27 & 40,30 \\
\hline & Kurang & 40 & 59,70 \\
\hline & Jumlah & 67 & 100 \\
\hline C. & Psikologis & & \\
\hline \multirow[t]{4}{*}{1.} & Merasa Kesulitan Dalam Belajar & & \\
\hline & Ya & 37 & 55,22 \\
\hline & Tidak & 30 & 44,78 \\
\hline & Jumlah & 67 & 100 \\
\hline \multirow[t]{4}{*}{2.} & Ingin Terlihat Keren & & \\
\hline & Ya & 40 & 59,70 \\
\hline & Tidak & 27 & 40,30 \\
\hline & Jumlah & 67 & 100 \\
\hline \multirow[t]{4}{*}{3.} & Ingin Mencoba Merokok & Jumlah & Persentase \\
\hline & Ya & 60 & 89,56 \\
\hline & Tidak & 7 & 10,44 \\
\hline & Jumlah & 67 & 100 \\
\hline \multirow[t]{4}{*}{ D. } & Tindakan & Jumlah & Persentase \\
\hline & Baik & 27 & 40,30 \\
\hline & Kurang Baik & 40 & 59,70 \\
\hline & Jumlah & 67 & 100 \\
\hline
\end{tabular}

Sumber: Data Primer Diolah, 2020 
Tabel 3

Hasil Survei Enabling Factor dalam Perilaku Merokok pada Remaja di Desa Krajan Kecamatan Parang Kabupaten Magetan

\begin{tabular}{llll}
\hline No. & Faktor Perilaku & Frekuensi (n) & Persentase (\%) \\
\hline 1. & Tersedianya uang saku & & \\
& Ya & 67 & 100 \\
& Tidak & 0 & 0 \\
& Jumlah & 67 & 100 \\
\hline
\end{tabular}

Sumber: Data Primer Diolah, 2020

uang tidak terlalu besar). Uang saku merupakan pengembangan tanggung jawab, sehingga perlu disertai dengan penanaman nilai uang pada anak, sehingga uang yang diberikan oleh orang tua dengan perencanaan uang tersebut digunakan seperti untuk transportasi atau tabungan anak. Uang saku dapat digunakan untuk makan dan pengeluaran lain - lain. Jumlah uang saku harus disesuaikan dengan anggaran, usia, dan kondisi. Besar kecil uang saku yang diberikan untuk anak tergantung dari kemampuan ekonomi orang tuanya. Sarana dan prasarana yang berupa uang saku, fasilitas ini pada hakikatnya mendukung atau memungkingkan remaja dapat dengan bebas memperoleh perokok dan menjadi perokok, maka faktor-faktor ini disebut faktor pendukung atau faktor pemungkin (Alamsyah, 2009).

Uang saku menjadi sesuatu hal yang bisa diandalkan oleh remaja untuk membeli rokok, tanpa adanya uang saku dari orang tua, remaja tidak bisa untuk membeli rokok yang bisa dikatakan harga rokok terbilang mahal bagi seusia remaja. Pemberian uang saku yang berlebih mempunyai hubungan dengan praktik merokok responden. Uang saku responden selain untuk membeli makanan atau jajanan ringan setengah dari uang saku tersebut dibelikan rokok di warung-warung yang menyediakan rokok, bahkan sebagian remaja rela uang sakunya tidak dibelikan makanan atau jajan demi sebatang rokok untuk mereka hisap (Cahyo, 2012). Pemberian uang saku yang jumlahnya berlebihan dapat disalahgunakan untuk melakukan perilaku salah seperti merokok. Hasil studi ini didukung oleh hasil penelitian yang menyatakan bahwa terdapat korelasi positif antara jumlah uang saku dan konsumsi rokok pada remaja (Scragg, et al, 2002).
Hasil survei menunjukkan bahwa faktor pendorong (reinforcing factor) yang dominan dalam penelitian ini adalah faktor teman sebaya yakni teman merokok sebanyak 55 orang $(82,09 \%)$ dan ajakan teman sebanyak 50 orang (74,63\%). Hasil survei menunjukkan bahwa remaja perokok memiliki teman perokok juga dimana jumlahnya lebih banyak dibandingkan dengan teman yang tidak merokok. Berdasarkan hasil tersebut dapat diketahui bahwa semakin responden memiliki banyak teman yang merokok semakin tinggi pula tingkat remaja untuk melakukan tindakan merokok. Hal ini sejalan dengan teori yang mengungkapkan bahwa semakin banyak remaja merokok, maka semakin besar kemungkinan teman-temannya menjadi perokok juga. Hal ini dapat dilihat dari dua kemungkinan yang terjadi, pertama remaja tersebut terpengaruh oleh teman-temannya sedangkan yang kedua, teman-temanya yang dipengaruhi oleh remaja tersebut sehingga akhirnya semua menjadi perokok (Alamsyah, 2009). Teman sebaya adalah orang dengan tingkat umur dan kedewasaan yang kira-kira sama. Teman sebaya merupakan anak-anak dengan tingkat kematangan atau usia yang kurang lebih sama. Salah satu fungsi penting dari kelompok teman sebaya adalah untuk memberikan sumber informasi tentang dunia di luar keluarga. Anak-anak akan menilai apa yang mereka lakukan, apakah lebih baik, sama, atau lebih buruk dari temannya. Penelitian ini juga didukung oleh penelitian yang dilakukan oleh Baharuddin (2017), yang menunjukkan bahwa ada perbedaan perilaku merokok antara siswa yang memiliki teman perokok dan yang tidak memiliki teman perokok, atau ada hubungan yang bermakna antara yang memiliki teman perokok dengan perilaku merokok pada responden. Remaja yang merokok mengakui 
bahwa dengan mereka melihat beberapa temannya yang melakukan tindakan merokok, dalam dirinya timbul rasa penasaran dan rasa ingin mencoba, pada akhirnya mereka mencoba melakukan tindakan merokok dan berlanjut menjadi kebiasaan merokok dalam kehidupan sehari-hari, terutama disaat bertemu dengan teman/ disaat sedang berkumpul dengan teman sepergaulannya.

Lingkungan teman sebaya merupakan suatu interaksi dengan orang-orang yang mempunyai kesamaan dalam usia, status sosial, hobi dan pemikiran yang sama, dalam berinteraksi mereka akan mempertimbangkan dan lebih memilih bergabung dengan orangorang yang mempunyai kesamaan dalam halhal tersebut (Slavin, 2011). Dalam kelompok teman sebaya individu akan merasakan adanya persamaan satu dengan yang baik usia, status sosial, kebutuhan, dan tujuan untuk memperkuat kelompok itu, sehingga individu didalam kelompok tersebut akan merasa menemukan dirinya dan akan mengembangkan rasa sosialnya seiring dengan perkembangan kepribadiannya (Santosa, 2009). Berdasarkan Penelitian yang dilakukan oleh Melda (2017), menunjukkan bahwa faktor lingkungan teman sebaya atau teman sepermainan dapat

Tabel 4

Penilaian Reinforcing Factor dalam Perilaku Merokok pada Remaja di Desa Krajan Kecamatan Parang Kabupaten Magetan

\begin{tabular}{|c|c|c|c|}
\hline No. & Faktor Perilaku & Frekuensi (n) & Persentase $(\%)$ \\
\hline A. & Orang Tua & & \\
\hline \multirow[t]{4}{*}{1.} & Orang tua merokok & & \\
\hline & Ya & 45 & 67,16 \\
\hline & Tidak & 22 & 32,84 \\
\hline & Jumlah & 67 & 100 \\
\hline \multirow[t]{4}{*}{2.} & Orang Tua Bercerai & & \\
\hline & Ya & 25 & 37,31 \\
\hline & Tidak & 42 & 62,69 \\
\hline & Jumlah & 67 & 100 \\
\hline \multirow[t]{4}{*}{3.} & Tidak tinggal dengan orang tua & & \\
\hline & Ya & 15 & 22,39 \\
\hline & Tidak & 52 & 77,61 \\
\hline & Jumlah & 67 & 100 \\
\hline B & Teman Sebaya & & \\
\hline \multirow[t]{4}{*}{1.} & Teman Merokok & & \\
\hline & Ya & 55 & 82,09 \\
\hline & Tidak & 12 & 17,91 \\
\hline & Jumlah & 67 & 100 \\
\hline \multirow[t]{4}{*}{2.} & Ajakan Teman Merokok & & \\
\hline & Ya & 50 & 74,63 \\
\hline & Tidak & 17 & 25,37 \\
\hline & Jumlah & 67 & 100 \\
\hline \multirow[t]{4}{*}{ C. } & Iklan & & \\
\hline & Ya & 41 & 61,19 \\
\hline & Tidak & 26 & 38,81 \\
\hline & Jumlah & 67 & 100 \\
\hline
\end{tabular}

Sumber: Data Primer Diolah, 2020 
mempengaruhi remaja merokok karena adanya ajakan dan pengaruh yang sangat kuat dalam mendorong munculnya perilaku merokok terhadap remaja yang tidak merokok.

Hasil survei faktor orang tua merokok dan iklan masing-masing mempunyai peranan sebesar $67,16 \%$ (45 responden) dan $61,19 \%$ (41 responden) terhadap perilaku remaja dalam merokok di Desa Krajan Kecamatan Parang Kabupaten Magetan. Keluarga adalah unit terkecil dari masyarakat yang tersusun atas kepala keluarga (berperan sebagai suami dan ayah) dan beberapa orang yang terkumpul dan tinggal bersama pada suatau tempat di bawah satu atap dalam kondisi yang saling membutuhkan/ketergantungan. Keluarga atau orang tua adalah pendidikan pertama bagi anak-anaknya mulai dari anak usia dini sampai usia dewasa. Orang tua adalah orang atau figure contoh bagi anak-anaknya, orang tua perokok maka anak akan mungkin sekali untuk mencontoh orang tuanya dalam hal merokok sama seperti orang tuanya (Alamsyah, 2009). Berdasarkan penelitian yang dilakukan oleh Baharudin (2017), menunjukkan bahwa ada perbedaan perilaku merokok antara siswa yang memiliki orang tua perokok dan yang tidak memiliki orang tua perokok atau ada hubungan yang bermakna antara yang memiliki orang tua dengan perilaku merokok responden.

Iklan adalah suatu pesan tentang barang/ jasa (produk) yang dibuat oleh produser/ pemrakasa yang disampaikan lewat media (cetak, audio, elektronik) yang di tujukan kepada masyarakat. Tujuan iklan adalah agar masyarakat tertarik untuk membeli atau menggunakan barang atau jasa tersebut. Iklan rokok merupakan iklan yang ada di media massa dan elektronik yang menampilkan bahwa perokok adalah lambang kejantanan atau glamor membuat remaja seringkali terpicu untuk mengikuti perilaku seperti iklan tersebut. Berdasarkan penelitian menunjukkan bahwa faktor media iklan juga menjadi salah satu hal yang mempengaruhi remaja merokok karena dari media iklan baik media massa seperti media cetak, media elektronik dan media sosial mampu memberikan informasi mengenai iklaniklan rokok yang mampu mendorong remaja dalam aktivitas merokok (Melda 2017).

\section{SIMPULAN}

Faktor yang dominan terkait dengan perilaku remaja dalam merokok di Desa Krajan Kecamatan Parang Kabupaten Magetan yaitu keinginan mencoba (Presdisposing factor), uang saku (Enabling factor), teman sebaya perokok dan ajakan teman (Reinforcing factor). Perlu dilakukan edukasi kepada remaja yang merokok di desa Krajan kecamatan Parang kabupaten Magetan tentang bahaya dan dampak dari merokok agar remaja paham dan berhenti untuk merokok.

\section{DAFTAR PUSTAKA}

Alamsyah, R.M. Faktor-faktor yang mempengaruhi kebiasaan merokok dan hubungannya dengan status penyakit periodontal remaja kota medan" Tesis S2 Universitas Sumatra Utara. Medan: 2009.

Baharuddin. 2017. Faktor - Faktor Yang Berhubungan Dengan Perilaku Merokok Pada Anak Usia Remaja Madya (15-18 Tahun). Skripsi. Fakultas Kedokteran Dan Ilmu Kesehatan Universitas Islam Negeri Alauddin Makassar.

Cahyo, K., Wigati, P.A, Shaluhiyah, Z. 2012. Rokok, pola pemasaran dan perilaku merokok siswa SMA/sederajat di Kota Semarang. Media Kesehatan Masyarakat Indonesia, 11(1), 75-85. Retrieved from file://C:/Users/User/Downloads/616713285-1-SM\%20(2).pdf8472.

Fatmawati (2010). Faktor Keluarga Yang Mempengaruhi Perilaku Merokok Pada Siswa Sekolah Menengah Pertama. Jurnal Ilmu Keperawatan, 4(1).

Febrijanto, Y., \& Fikriyah, S. 2012. FaktorFaktor Yang Mempengaruhi Perilaku Merokok Pada Mahasiswa Laki-Laki Di Asrama Putra Factors That Influence the Smoking Behaviour of Male Students in Dormitories S. Jurnal Penelitian STIKES Kediri, 5(1), 99-109. Retrieved from http://cpanel.petra.ac.id/ejournal/ index.php/stikes/article/view/18472. 
InfoDatin. 2015. Hari Tanpa Tembakau Sedunia, Pusat Data dan Informasi Kementerian Kesehatan RI, Jakarta.

Kemenkes RI, 2019. Prevelansi Perokok LakiLaki di Indonesia. Jakarta: Depkes RI.

Komasari, D. 2013. Faktor Faktor Penyebab Merokok Pada Remaja. Psikologi, 3747(1), 37-47.

Melda, S. 2017. Faktor-faktor penyebab remaja merokok (studi kasus remaja laki-laki di Kelurahan Karang Asam Ulu Kecamatan Sungai Kunjang, Kota Samarinda, Journal Sosiatri-Sosiologi Fakultas Ilmu Sosial dan Ilmu Politik Universitas Mulawarman, 5(4), pp. 102-116.

Notoatmodjo, Soekidjo. 2007. Promosi Kesehatan dan Perilaku Kesehatan. Jakarta: Rineka Cipta.

Purnomo, B. I., Roesdiyanto, \& Gayatri, R. W. (2018). Hubungan Faktor Predisposisi, Faktor Pemungkin dan Faktor Penguat dengan Perilaku Merokok Pelajar SMKN 2 Kota Probolinggo tahun 2017. Preventia Journal, 3(1).
Rochayati, AS, Hidayat, E 2015, Faktorfaktor yang mempengaruhi perilaku Merokok Remaja Di Sekolah Menengah Kejuruan Kabupaten Kuningan, Jurnal Keperawatan Soedirman, 1(10), pp. $1-11$.

Santoso, Slamet.2006. Dinamika Kelompok. Jakarta : Bumi Aksara.

Scragg, R. 2002. Cigarette smoking, pocket money and socioeconomic status : results from a national survey of 4th from students in 2000. The New Zealand Medical Journal, 115(1158), pp. 1-8.

Shaluhiyah, Z., Karyono \& Noor, F., 2006. Faktor-Faktor Yang Berpengaruh Terhadap Praktik Merokok Pada. Promosi Kesehatan Indonesia, Vol. 1/No., pp.18. http://download.portalgaruda.org/arti cle.php?article $=21985 \&$ val $=1285$.

Slavin, Robert E, 2008. Cooperative Learning Teori Riset dan Praktik Terjemahan Lita. Bandung: Nusa Media. 